\title{
ANALYSIS OF THE PROFESSIONAL SATISFACTION OF PHARMACISTS IN BRATISLAVA
}

\author{
Zuzana Koblišková, ${ }^{1}$ Zuzana Haramiová, ${ }^{2}$ Tomáš Tesařr
}

\begin{abstract}
A pharmacist is an expert on medications. At the same time as the most accessible health care provider, the pharmacist fulfills an important social mission. For a pharmacist, work satisfaction plays an important role in several aspects of his practice in a pharmacy. Our primary goal was to conduct a local analysis with the purpose of testing the proposed questionnaire evaluating various dimensions of the professional satisfaction of pharmacists. Our secondary goals were as follows: to analyze individual dimensions of pharmacists' professional satisfaction, to assess the quality of life in the context of the pharmacists' professional satisfaction and to analyze the impact of selected characteristics (age, location of the pharmacy) on the pharmacists' quality of life. The study is based on a questionnaire survey among pharmacists in Bratislava from July to September 2016. Data were collected in person. Respondents were randomly selected from community pharmacies., Equal number of respondents were selected from three different types of pharmacies: a) public pharmacy or its branch in a medical facility or a health centre b) public pharmacy or its branch in a shopping centre c) public pharmacy or its branch in a residential housing development. The results of the study show that the professional satisfaction of pharmacists in Bratislava is evaluated positively. Out of all 27 questions of the questionnaire, only three were evaluated negatively. The analysis points out that pharmacists are dissatisfied with the conditions in the workplace, regulation and legal responsibilities stemming from the profession of a pharmacist, healthcare system, and health insurance companies. The majority of the pharmacists characterized their state of mind on the job as concentrated. Older respondents were more tired and less energized. With regards to the location of a pharmacy, respondents that work in pharmacies located in residential housing developments feel the most concentrated. The knowledge of needs and problems of the profession is the essential precondition for its continued successful development, and its position in current as well as future European and Slovak healthcare systems. Until now, the quality of the professional life of pharmacists has not become a subject of systematic research and evaluation in Slovakia. Our study showed that the professional satisfaction of pharmacists in Bratislava is evaluated positively.
\end{abstract}

UDC Classification: 159.96; DOI: http://dx.doi.org/10.12955/cbup.v5.1003

Keywords: pharmacist, professional satisfaction, pharmaceutical care

\section{Introduction}

\section{Pharmaceutical care}

Slovak Act No. 362/2011 Coll. defines pharmaceutical care as one of the three forms of health care provision, and from the perspective of the Slovak legislation, it covers the providing, preparation, inspection, storage, dispensation of medications with the exception of preparation of transfusion medications and medical aids, mail order dispensation, providing expert advice about medications and medical aids, and consultations with regard to determination and monitoring of the treatment. Pharmaceutical care is provided: 1 . in public pharmacies that are set up as educational bases 2 . in public pharmacies and branches of public pharmacies 3. in hospital pharmacies 4. in dispensaries of medical aids 5. in dispensaries of orthopedic and prosthetic medical aids. Stanko \& Minarovič (2011) state that based on the legislation of definitions and the conception of pharmaceutical care development defined by international authorities in the field of health and pharmacy, basic roles, and functions in the pharmaceutical care system can be categorised according to the character of individual activities into following groups: a) logistics b) dispensation c) consulting d) distribution e) screening and monitoring f) other activities.

\section{Professional satisfaction of pharmacists}

Snopková et al. (2014) argue that since pharmacists play a key role in informing patients about prescribed medications and ensuring suitability of the prescribed treatment, it is important to consider the question of which qualities of a pharmacists' work environment have a connection with the integration of the pharmacotherapeutic monitoring into the daily practice, and what obstacles are present in this process. For a pharmacist, the work satisfaction plays an important role in many aspects of his practice in a public pharmacy. A low level of work satisfaction can have a negative impact on his work performance. Dissatisfaction can also influence the way a pharmacist interacts with patients. Consequently, patients tend to limit their cooperation with a pharmacist. It is important to obtain information about pharmacists' attitudes toward performing their work, and about factors associated with their work attitudes. Given that healthcare workers can suffer from stress, especially due to the

\footnotetext{
${ }^{1}$ Faculty of Pharmacy, kobliskova@fpharm.uniba.sk

${ }^{2}$ Faculty of Pharmacy, haramiova@fpharm.uniba.sk

${ }^{3}$ Faculty of Pharmacy, tesar@fpharm.uniba.sk
} 
long-term effect of negative factors present in the workplace, their work attitudes should be examined. Matthew et al. (2008) describe the positive influence of pharmacists' work satisfaction as follows: 1) A satisfied pharmacist at work will positively impact his community; as a result, fewer work position changes occur 2) Work satisfaction of a pharmacist positively impacts his own mental and physical health. 3) A satisfied pharmacist positively impacts the patient and his health.

\section{Workload in the pharmaceutical profession}

McCann et al. (2009) emphasize that pharmacists today need to meet many high (professional, communication) demands. This fact is caused especially by a rising competition in healthcare and the need to improve healthcare services. This change may positively impact patient's satisfaction (Mináriková et al., 2015; Mináriková et al., 2016). This trend has shown to have an influence on the overall prosperity of community pharmacy and both accessibility and availability of pharmaceutical care (Malovecká et al., 2015, Malovecká et al., 2016). However, as a result, pharmacists at work often deal with stress and mental strain. Pelcák \& Tomeček (2011) define workload in a pharmacy as a sum of specific situations and activities (breach of the confidentiality zone, communication with problematic types of patients, dealing with complaints) that can be subjectively associated with mental burden. Consequently, cumulative stress can lead to professional failure or personality disintegration.

\section{Methodology}

The analysis of pharmacists' professional satisfaction in Bratislava was carried out between July and September 2016. Data collection was realized in person. Respondents were randomly approached in community pharmacies. We aimed at collecting responses from an equal number of respondents from three different types of pharmacies:

a) a public pharmacy or its branch in a medical facility or a health center

b) a public pharmacy or its branch in a shopping center

c) a public pharmacy or its branch in a residential housing development

In total, we obtained 25 questionnaires from each type of pharmacy. Overall, 75 respondents from a total number of 23 pharmacies participated in our research.

The questionnaire consisted of the following parts:

Dimension A: internal environment - altogether nine questions were allocated here, pertaining to the organization of a pharmacy as a workplace, work hours, and relationships in the workplace.

Dimension B: external environment -9 questions were allocated here, pertaining to legislative issues in providing pharmaceutical care, relationships with health insurance companies, professional organizations, and patients.

Dimension C: personal satisfaction -5 questions were allocated here, pertaining to personal matters such as financial remuneration, career advancement, etc.

Dimension D: quality of life -3 questions were allocated here, pertaining to a subjective assessment of the state of health, quality of life during the last month, and its comparison with the time period of 10 years ago.

Satisfaction was evaluated using 26 predetermined questions (Are you satisfied with...) using a 5-point Likert scale (no - more likely no - neither yes nor no - more likely yes - yes).

The results were processed using the Microsoft Excel program and expressed quantitatively (count, percentage). We consolidated the proportions of respondents from the Likert scale into three ranges as follows: 1) no / more likely no, 2) neither yes nor no, 3) more likely yes / yes.

\section{Results}

Dimension A was focused on evaluation of the internal environment. Here, pharmacists expressed the highest level of satisfaction (82.66\%) with the question concerning superior-subordinate communication. Satisfaction with a work team, the atmosphere in the workplace, communication of tasks, feedback based on work performance, and satisfaction with the support from the direct supervisor were rated highly positively $(81.33 \%)$. More than half of the respondents $(54.66 \%)$ were satisfied with the determination of work hours and the length of their work day. In this dimension of questions, respondents were the least satisfied with conditions in the workplace (satisfaction was expressed by only $33.33 \%$ of pharmacists). Table 1 displays the results from Dimension A in detail. 
Table 1: Respondents' satisfaction - dimension A = internal environment $(n=75)$

\begin{tabular}{|l|c|c|c|}
\hline & $\begin{array}{c}\text { No / more } \\
\text { likely no } \\
\text { n (\%) }\end{array}$ & $\begin{array}{c}\text { Neither yes nor } \\
\text { no } \\
\text { n (\%) }\end{array}$ & $\begin{array}{c}\text { More likely } \\
\text { yes / yes } \\
\text { n (\%) }\end{array}$ \\
\hline $\begin{array}{l}\text { Are you satisfied with the determination of your } \\
\text { work hours? }\end{array}$ & $19(20.00)$ & $15(20.00)$ & $44(54.66)$ \\
\hline $\begin{array}{l}\text { Are you satisfied with the length of your work } \\
\text { day? }\end{array}$ & $17(22.66)$ & $18(24.00)$ & $40(53.33)$ \\
\hline $\begin{array}{l}\text { Are you satisfied with other conditions in your } \\
\text { workplace (lighting, temperature, air } \\
\text { circulation, etc.)? }\end{array}$ & $34(45.33)$ & $16(21.33)$ & $25(33.33)$ \\
\hline Are you satisfied with your work team? & $8(10.66)$ & $6(8.00)$ & $61(81.33)$ \\
\hline $\begin{array}{l}\text { Are you satisfied with the superior-subordinate } \\
\text { communication? }\end{array}$ & $7(9.33)$ & $6(8.00)$ & $62(82.66)$ \\
\hline $\begin{array}{l}\text { Do you consider the atmosphere in your } \\
\text { workplace to be open and friendly? }\end{array}$ & $10(13.33)$ & $5(6.66)$ & $60(80.00)$ \\
\hline Are your tasks communicated clearly to you? & $9(12.00)$ & $7(9.33)$ & $59(78.66)$ \\
\hline $\begin{array}{l}\text { Are you satisfied with the support from your } \\
\text { direct supervisor? }\end{array}$ & $4(5.33)$ & $15(20.00)$ & $56(74.66)$ \\
\hline $\begin{array}{l}\text { Are you satisfied with the feedback you receive } \\
\text { based on your work performance? }\end{array}$ & $7(9.33)$ & $11(14.66)$ & $57(76.00)$ \\
\hline Source: Authors & & & \\
\hline
\end{tabular}

Dimension B assessed the external environment. Here, most positive aspects were: attitude and respect of patients and pharmacists' readiness for their profession during their studies. Cooperation with physicians and employment opportunities available abroad were also rated highly positively $(72.00 \%)$. Almost 59\% of the pharmacists were satisfied with the opportunities for continuing education and activities of professional and specialized organizations for pharmacists. In contrast, pharmacists expressed a high level of dissatisfaction $(77.33 \%)$ with the healthcare system, and with the cooperation with health insurance companies. Dissatisfaction with the regulation and legal responsibilities stemming from the pharmaceutical profession was expressed by almost $51 \%$ of respondents. Table 2 displays the results from Dimension B in detail.

Table 2: Respondents' satisfaction - dimension B = external environment $(n=75)$

\begin{tabular}{|l|c|c|c|}
\hline & $\begin{array}{c}\text { No / more likely } \\
\text { no } \\
\text { n (\%) }\end{array}$ & $\begin{array}{c}\text { Neither yes nor } \\
\text { no } \\
\text { n (\%) }\end{array}$ & $\begin{array}{c}\text { More likely yes / } \\
\text { yes } \\
\text { n (\%) }\end{array}$ \\
\hline $\begin{array}{l}\text { Are you satisfied with the attitude and respect } \\
\text { of patients toward you? }\end{array}$ & $9(12.00)$ & $10(13.33)$ & $56(74.66)$ \\
\hline $\begin{array}{l}\text { Are you satisfied with the cooperation with } \\
\text { physicians? }\end{array}$ & $10(13.33)$ & $11(14.66)$ & $54(72.00)$ \\
\hline $\begin{array}{l}\text { Are you satisfied with the opportunities for } \\
\text { continuing education? }\end{array}$ & $8(10.66)$ & $23(30.66)$ & $44(58.66)$ \\
\hline $\begin{array}{l}\text { Are you satisfied with activities of professional } \\
\text { and specialised organisations for pharmacists? }\end{array}$ & $14(18.66)$ & $19(25.33)$ & $42(56.00)$ \\
\hline $\begin{array}{l}\text { How satisfied are you with the regulation and } \\
\text { legal responsibilities stemming from the } \\
\text { profession of a pharmacist? }\end{array}$ & $38(56.66)$ & $20(26.66)$ & $17(22.66)$ \\
\hline $\begin{array}{l}\text { How much are you satisfied with the healthcare } \\
\text { system? }\end{array}$ & $58(77.33)$ & $9(12.00)$ & $8(10.66)$ \\
\hline $\begin{array}{l}\text { As a pharmacist, how satisfied are you with } \\
\text { health insurance companies? }\end{array}$ & $56(74.66)$ & $10(13.33)$ & $9(12.00)$ \\
\hline $\begin{array}{l}\text { Do you think you were prepared adequately for } \\
\text { the profession of a pharmacist during your } \\
\text { studies? }\end{array}$ & $11(14.66)$ & $9(12.00)$ & $55(73.33)$ \\
\hline $\begin{array}{l}\text { Do you think you would be able to find } \\
\text { employment as a pharmacist abroad? }\end{array}$ & $8(10.66)$ & $19(25.33)$ & $48(64.00)$ \\
\hline Source: Authors & & & \\
\hline
\end{tabular}


Dimension C concerned pharmacists' personal satisfaction. Here, responses were positive to all of the questions. The most positively rated aspect (100.00\%) was professional pride. Pharmacists expressed a high level of satisfaction with their work position and job content $(78.66 \%)$, and relaxed feeling at work (77.33\%). Furthermore, $68.00 \%$ of pharmacists expressed satisfaction with the acceptance of their proposals and requests in the workplace and $60.00 \%$ with their financial remuneration. Table 3 displays the results from Dimension $C$ in detail

\begin{tabular}{|l|c|c|c|}
\hline Table 3: Respondents' satisfaction - dimension C $=$ personal satisfaction $(\mathrm{n}=75)$ \\
\hline & $\begin{array}{c}\text { No / more } \\
\text { likely no } \\
\mathbf{n}(\%)\end{array}$ & $\begin{array}{c}\text { Neither yes nor } \\
\text { no } \\
\mathbf{n}(\%)\end{array}$ & $\begin{array}{c}\text { More likely } \\
\text { yes / yes } \\
\text { n (\%) }\end{array}$ \\
\hline $\begin{array}{l}\text { Are you satisfied with your financial } \\
\text { remuneration? }\end{array}$ & $16(21.33)$ & $14(18.66)$ & $45(60.00)$ \\
\hline $\begin{array}{l}\text { Are you satisfied with the acceptance of your } \\
\text { proposals and requests in the workplace? }\end{array}$ & $8(10.66)$ & $16(21.33)$ & $51(68.00)$ \\
\hline $\begin{array}{l}\text { Does your current work position and job content } \\
\text { meet your expectations? }\end{array}$ & $7(9.33)$ & $9(12.00)$ & $75(78.66)$ \\
\hline Overall, do you feel relaxed at work? & $4(5.33)$ & $13(17.33)$ & $58(77.33)$ \\
\hline Are you proud of being a pharmacist? & $0(0.00)$ & $0(0.00)$ & $75(100.00)$ \\
\hline Source: Authors
\end{tabular}

All aspects within Dimension D evaluating pharmacists' quality of life were rated positively. Pharmacists were most satisfied with their quality of life in the last month $(76.00 \%)$ and their current overall physical and mental health $(74.66 \%)$. The question in which pharmacists were asked to compare their current quality of life with their quality of life 10 years ago, was rated positively as well. Table 4 displays the results from Dimension D in detail.

\begin{tabular}{||l|c|c|c|}
\hline \multicolumn{5}{|l|}{ Table 4: Respondents' satisfaction - dimension $\mathrm{D}=$ quality of life $(\mathrm{n}=75)$} \\
\hline & $\begin{array}{c}\text { No / more } \\
\text { likely no } \\
\mathbf{n}(\%)\end{array}$ & $\begin{array}{c}\text { Neither yes nor } \\
\text { no } \\
\mathbf{n}(\%)\end{array}$ & $\begin{array}{c}\text { More likely } \\
\text { yes / yes } \\
\text { n }(\%)\end{array}$ \\
\hline $\begin{array}{l}\text { Are you satisfied with your current overall } \\
\text { physical and mental health: }\end{array}$ & $4(5.33)$ & $15(20.00)$ & $56(74.66)$ \\
\hline $\begin{array}{l}\text { Have you been satisfied with your overall } \\
\text { quality of life in the last month? }\end{array}$ & $4(5.33)$ & $14(18.66)$ & $57(76.00)$ \\
\hline $\begin{array}{l}\text { Is your current quality of life better than it } \\
\text { was 10 years ago? }\end{array}$ & $6(8.00)$ & $18(24.00)$ & $51(68.00)$ \\
\hline Source: Authors
\end{tabular}

Analysis of the impact of selected characteristics on the pharmacists' quality of life

The results of the analysis show that the majority of pharmacists in each age group described their state of mind on the job as "concentrated" (Table 5, Figure 1). Pharmacists aged 31-45 feel the most "concentrated" (79.31\%) on the job, while the least "concentrated" on the job is the youngest group of respondents. Our analysis suggests that there is a correlation between the respondents' age and state of mind while performing their work at a pharmacy: the older the respondents were, the more "tired" and "less energized" they felt.

\begin{tabular}{|c|c|c|c|}
\hline Age & Tired, n (\%) & Concentrated, n (\%) & Energised, n (\%) \\
\hline$\leq 30$ years of age & $1(3.33)$ & $15(50.00)$ & $14(46.66)$ \\
\hline 31-45 years of age & $2(6.89)$ & $23(79.31)$ & $4(13.79)$ \\
\hline 46-61 years of age & $4(13.79)$ & $10(66.66)$ & $1(6.66)$ \\
\hline$>61$ years of age & $1(100.00)$ & $0(0.00)$ & $0(0.00)$ \\
\hline
\end{tabular}




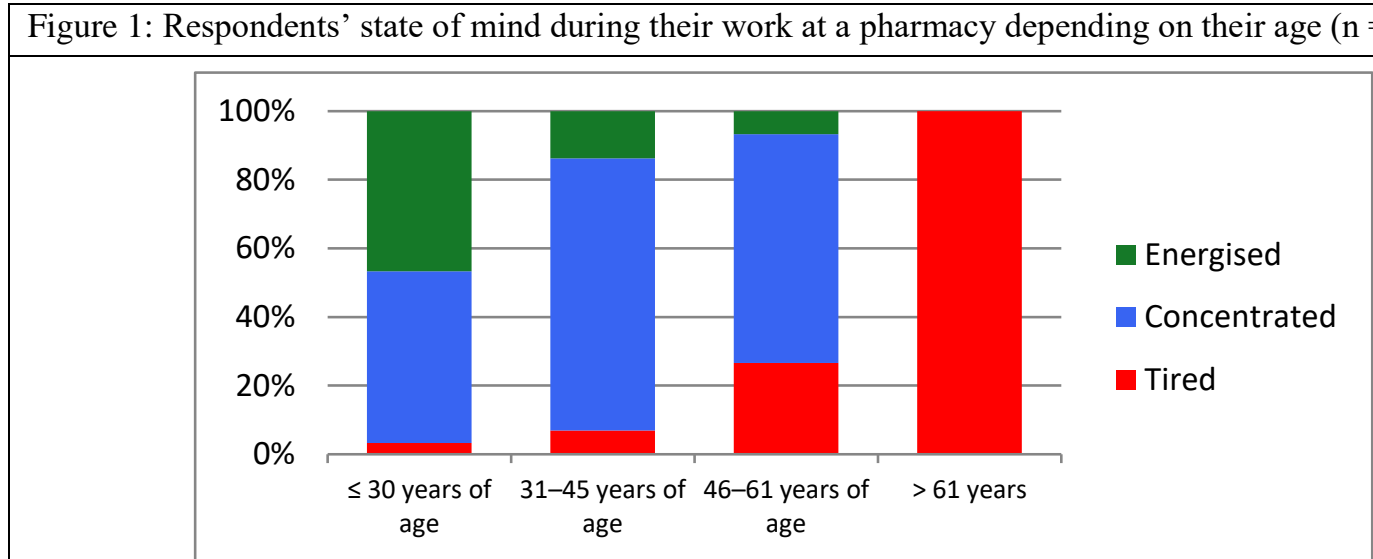

Source: Authors

In regard to the pharmacy location, respondents working in pharmacies localized in residential housing developments feel most "concentrated" $(76.00 \%)$. Pharmacists working in shopping centers feel least "concentrated," while at the same time, they are the most tired of all pharmacists.

Table 6: Respondents' state of mind during their work at a pharmacy depending on the location of a pharmacy $(\mathrm{n}=75)$

\begin{tabular}{|l|c|c|c|}
\hline Location of the pharmacy & Tired, $\mathbf{n}(\boldsymbol{\%})$ & Concentrated, $\mathbf{n}(\boldsymbol{\%})$ & Energised, $\mathbf{n}(\boldsymbol{\%})$ \\
\hline $\begin{array}{l}\text { Medical facility or health } \\
\text { centre }\end{array}$ & $2(8.00)$ & $15(60.00)$ & $8(32.00)$ \\
\hline Shopping centre & $5(20.00)$ & $14(56.00)$ & $6(24.00)$ \\
\hline $\begin{array}{l}\text { Residential housing } \\
\text { development }\end{array}$ & $1(4.00)$ & $19(76.00)$ & $5(20.00)$ \\
\hline Source: Authors & \\
\hline
\end{tabular}

Figure 2: Respondents' state of mind during their work at a pharmacy depending on the location of a pharmacy $(n=75)$

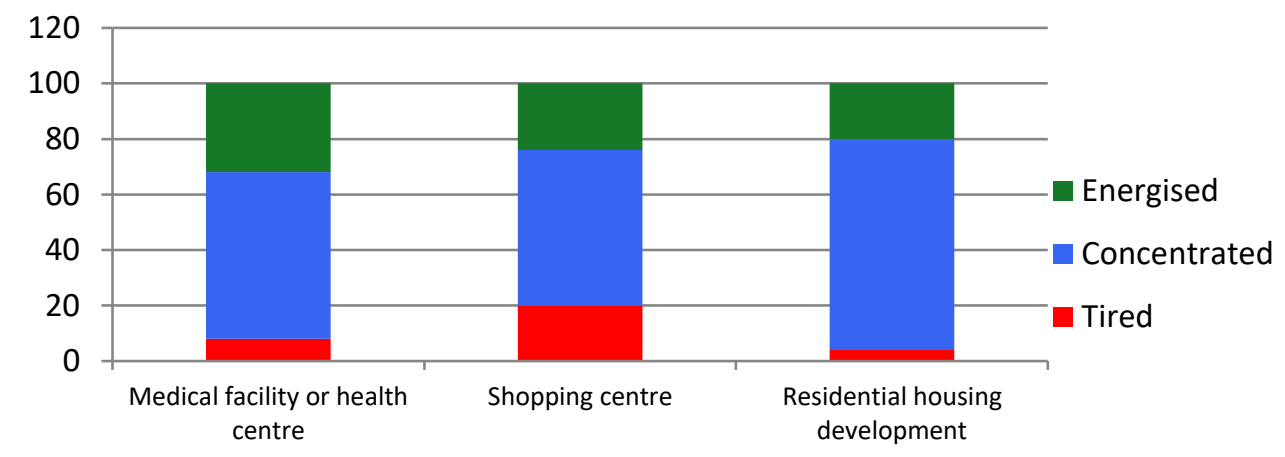

Source: Authors

\section{Discussion}

Increasing demands on professional and communication competencies, rising competition in healthcare, and integration of healthcare services all impact sustainability of a traditional manner of pharmacy development. The emphasis on quality of pharmaceutical care lies above all in the responsibility toward the patient. Nowadays, it is important to give enough space to the satisfaction of professionals pharmacists as well and to look for new opportunities to improve their professional life. A positive evaluation emerged from a study of the American Pharmaceutical Association, regarding the quality of professional life of pharmacists in a pharmacy environment, and focused on issues pertaining to work satisfaction, career advancement, realisation of plans of organizations, and patient care. However, it discovered differences in the quality of professional life related to practice in the area of primary care, 
depending on demographic and gender variables. Urbonas et al., 2010 conducted a study in Lithuania focused on the professional satisfaction of pharmacists. This study analyzed the attitudes of pharmacists toward the quality of pharmaceutical care. Their results showed the positive evaluation of pharmaceutical care by the pharmacists. However, the individual healthcare systems of the European Union still do not pay enough attention to the professional satisfaction of pharmacists. Moreover, financial remuneration impacts the quality of pharmaceutical care as well. The study carried out by Mosadeghrad et al., 2008 endorse the fact that financial remuneration could increase the level of professional satisfaction of pharmacists, and thus improve the quality of provided health services.

\section{Conclusion}

Patient satisfaction is one of the main indicators of the quality of provided pharmaceutical services. The identification of weak points in the pharmaceutical profession and subsequent targeted solutions open possibilities for increasing professional satisfaction and self-confidence of pharmacists as healthcare workers. The knowledge of needs and problems of the profession is the essential precondition for its continued successful development, and its position in current as well as future European and Slovak healthcare systems. Our primary goal was to carry out a local analysis using a questionnaire evaluating various dimensions of the professional satisfaction of pharmacists. We have analyzed individual dimensions of pharmacists' professional satisfaction, assessed their quality of life in the context of their professional satisfaction and evaluated the impact of selected characteristics (age, location of the pharmacy) on their quality of life. The results of our study suggest that professional satisfaction of pharmacists in Bratislava is evaluated positively.

\section{References}

Malovecká, I., Papargyris, K., Mináriková, D., Foltán, V., \& Jankovská, A. (2015). Prosperity of community pharmacy evaluated by gross and net profit and suggested corrective measures. 10 years study Acta Facultatis Pharmaceuticae Universitatis Comenianae (Vol. 62, pp. 20).

Malovecká, I., Szücs, G., \& Fazekaš, T. (2016). Community pharmacies in Slovakia in 1998-2014. Farmaceutický obzor, 85(3), 51-57.

Matthew M, M., Payakachat, N., \& Koh-Knox, C. (2008). Factors affecting job and career satisfaction among community pharmacists: A structural equation modeling approach. Journal of the American Pharmacists Association, 48(5), 610-620. doi:10.1331/JAPhA.2008.07083

McCann, L., Hughes, C. M., Adair, C. G., \& Cardwell, C. (2009). Assessing job satisfaction and stress among pharmacists in Northern Ireland. Pharmacy World \& Science, 31(2), 188. doi:10.1007/s11096-008-9277-5

Mináriková, D., Malovecká, I., \& Foltán, V. (2015). Consumer satisfaction with pharmaceutical care in Slovak community pharmacies / Spokojnost' klientov lekární s lekárenskou starostlivost'ou na Slovensku Acta Facultatis Pharmaceuticae Universitatis Comenianae (Vol. 62, pp. 25).

Mináriková, D., Malovecká, I., \& Foltán, V. (2016). Patient choice of pharmacy and satisfaction with pharmaceutical care slovak regional comparison. Farmacia, 64(3), 473-480.

Mosadeghrad, A. M., Ferlie, E., \& Rosenberg, D. (2008). A study of the relationship between job satisfaction, organizational commitment and turnover intention among hospital employees. Health Services Management Research, 21(4), 211-227. doi:10.1258/hsmr.2007.007015

Pelcák, S., \& Tomeček, A. (2011). Syndróm vyhorení -psychické důsledky výkonu práce Expedienta. Praktické lekárnictvo, 7(2), 87-90.

Snopková, M., Mináriková, D., \& Fulmeková, M. (2014). Profesijná spokojnost’ lekárnikov na Slovensku. Praktické lekárnictvo, 4(4), 116-119.

Stanko, P., \& Minarovič, I. (2011). Základné úlohy a funkcie systému lekárenskej starostlivosti. Praktické lekárnictvo, 1(4), 199-200.

Urbonas, G., Jakusovaite, I., \& Savickas, A. (2010). Pharmacy specialists' attitudes toward pharmaceutical service quality at community pharmacies. Medicina (Kaunas), 46(10), 686-692.

Zákon č. 362/2011 Z.z. o liekoch a zdravotníckych pomôckach [Act No. 362/2011 Coll. on drugs and medical devices], NR $\mathrm{SR},(2011)$ 